\title{
Respon Pemberian Hormon 2,4-D dan BAPterhadap Pertumbuhan Subkultur Kalus Kedelai (Glycine max (L.) Merrill) secara In Vitro
}

\author{
Kiki Ayuningrum, Iman Budisantoso ${ }^{1)}$ dan Kamsinah'1) \\ ${ }^{1)}$ Fakultas Biologi, Universitas Jenderal Soedirman \\ JI. Dr. Suparno, Karangwangkal, Purwokerto, 53122. \\ Alamat korespondensi : kikiayuningrum@gmail.com
}

\begin{abstract}
The purpose of this study was to evaluate the response of administration of a combination of 2,4$\mathrm{D}$ and BAP on the growth of soybean callus subculture and determine the combination of 2,4-D and BAP most good for the growth of soybean callus subculture. The study design used completely randomized design (CRD) with a pattern factorials. The factor one e.i 2,4-D consists of 4 levels, namely: 0, 5, 10, and $15 \mathrm{ppm}$. A factor of 2 e.iBAP consists of 4 levels, namely: 0, 2, 4, dan $6 \mathrm{ppm}$. Every combination treatment repeated three times.Parameters measured include the percentage is growing callus, type of callus, dry weight and wet weight of soybean callus. The results showed that administration of the hormone 2,4-D and BAP can spur the growth of soybean callus subculture, the combination of BAP 2 ppm and $10 \mathrm{ppm}$ of 2,4-D is the best combination for a percentage of callus and growing callus types, whereas the wet weight and the weight dried callus is not driven by a combination of the hormone 2,4-D and BAP.
\end{abstract}

Keywords: 2,4-D,BAP, calliculture, soybean.

\section{Abstrak}

Tujuan penelitian ini adalah untuk mengetahui respon pemberian kombinasi 2,4-D dan BAP terhadap pertumbuhan subkultur kalus kedelai dan menentukan kombinasi 2,4-D dan BAP yang paling baik untuk pertumbuhan subkultur kalus kedelai. Rancangan penelitian yang digunakan adalah Rancangan Acak Lengkap (RAL) dengan pola faktorial. Faktor yang dicobakan terdiri atas: 2,4-D dengan 4 taraf yaitu: $0,5,10$, dan $15 \mathrm{ppm}$,BAPdengan 4 taraf yaitu: 0,2 , 4, dan $6 \mathrm{ppm}$. Tiap perlakuan diulang 3 kali. Parameter yang diukur meliputi presentase tumbuh kalus, tipe kalus, berat kering serta berat basah kalus kedelai.Hasil penelitian menunjukkan bahwa pemberian hormon 2,4-D dan BAP dapat memacu pertumbuhan subkultur kalus kedelai, kombinasi BAP 2 ppm dan 2,4-D 10 ppm merupakan kombinasi terbaik untuk prosentase kalus dan tipe kalus yang tumbuh, sedangkan pada berat basah dan berat kering kalus tidak dipacu oleh kombinasi pemberian hormon 2,4-D dan BAP.

Kata kunci : 2,4-D, BAP, kultur kalus, kedelai.

\section{Pendahuluan}

Tanaman kedelai merupakan salah satu tanaman multiguna karena biasa digunakan sebagai bahan pangan, pakan ternak, maupun bahan baku berbagai industri manufaktur (pabrik) dan olahan. Kedelai mengandung kadar protein lebih dari $40 \%$, lemak $10-15 \%$ dan vitamin (Adisarwanto, 2005). Kendala utama penurunan produksi kedelai antara lainbenih yang tersedia berkualitas rendah serta pengendalian terhadap serangan hama dan penyakit tanaman yang belum memadai.Salah satu alternatif untuk mengatasi kendala tersebut yaitu melalui perbanyakan tanaman dengan teknik kultur invitro. Manfaat dari kultur invitroyaitu menyediakan bibit tanaman yang sehat dalam jumlah banyak, wakturelatif singkat, dalam areal yang sempit, tidak tergantung pada musim. Penerapan metode kultur invitro merupakan langkah awal untuk mendapatkan perbaikan kualitas tanaman (Yusnita, 2004).

Respon pertumbuhan kultur invitro secara umum meliputi pembentukan kalus atau embriosomatik, kemudian akan mengalami diferensiasi yang akan membentuk organ apabila dipacu dengan zat pengatur tumbuh. Differensiasi dapat terjadi melalui dua cara, yaitu diferensiasi langsung, dimana pembentukan organ tanpa melalui pembentukan kalus dan diferensiasi tak langsung, yaitu terbentuknya organ didahului dengan pembentukan kalus dan organ akan muncul dari kalus tersebut (George dan Sherington, 1984).

2,4-D merupakan ZPT yang paling sering digunakan untuk induksi dan pertumbuhan kalus karena efektif untuk 
tahap inisiasi khususnya pada jaringan yang belum dewasa. Selain itu, 2,4-D bersifat stabil pada suhu yang tinggi, sangat reaktif, efektif pada konsentrasi yang rendah dan aktif dalam waktu yang lama. 2,4-D yang digunakan dalam konsentrasi yang rendah juga dapat mendorong pembelahan sel, mendorong pertumbuhan tanaman dan meningkatkan daya kecambah benih (Wattimena, 2001). Syahid dan Hernani (2001), menambah-kan bahwa 2,4-D mampu merangsang pembentukan kalus.

Penggunaan ZPT 2,4-D pada induksi kalus embriogenik telah dicoba pada beberapa jenis tanaman. Menurut Khumaida dan Handayani (2010), kemampuan induksi dan proliferasi kalus embriogenik dari eksplan kotiledon muda kedelai dipengaruhi oleh genotipe dan jenis auksin yang digunakan, pada tahap induksi maupun proliferasi kalus embrio-genik dengan menggunakan media MS (vitamin B5, sukrosa $3 \%$, gelrite $0,2 \%, 5 \mathrm{mg} / \mathrm{l} 2,4-\mathrm{D}$ dan 5 mg/l NAA) memberikan respon yang lebih baik dari media lainnya. Setyaningrum (2011) menambahkan bahwa zat pengatur tumbuh 2,4-D mutlak diperlukan untuk menginduksi kalus. Menurut penelitian Widoretno et al. (2003), penambahan hormon 2,4-D dengan konsentrasi 10 ppm cukup baik untuk menginduksi kalus dan pembentuk-an embrio somatik.

Hasil penelitian Gangga (2007), kalus biji buah mahkota dewa yang ditanam pada media MS dengan penambahan 2,4-D tumbuh optimal pada konsentrasi $2 \mathrm{ppm} / \mathrm{l}$, pada tahap inisiasi kalus, eksplan yang ditanam pada media MS yang ditambah dengan 2 ppm 2,4-D dan 1 ppm BAP pada minggu kedua sudah mulai terbentuk kalus dan pertumbuhan kalus yang sempurna terjadi pada minggu kedelapan. Penggunaan hormon 2,4-D sangat berguna untuk menghambat proses morfogenesis pada kalus sehingga mampu menginisiasi pertumbuhan kalus. Minggu keenam kalus sudah dapat digunakan untuk perbanyakan dengan cara disubkulturkan. Konsentrasi 2,4-D 2 ppm dan BAP 1 ppm baik untuk perbanyakan kalus (subkultur kalus). Menurut Wattimena (2001), pada induksi kalus kacang tanah pada media MS dengan penambahan 2,4-D dengan konsentrasi 1 $\mathrm{mg} / \mathrm{l}$ eksplan dapat tumbuh dengan baik.

\section{Materi dan Metode}

Metode penelitian yangdigunakan adalah metode eksperimental dengan menggunakan Rancangan Acak Lengkap (RAL) dengan pola faktorial yang terdiri dari dua faktor, yaitu : BAP dengan empat 4 taraf 0; 4; 2dan6 ppm; serta2,4-D dengan 4 taraf yaitu 0;10;5;15 ppm. Tiap perlakuan diulang 3 kali. Media yang digunakan adalah media dasar MS.

Parameter yang diamati dalam penelitian ini meliputi prosentase kalus yang tumbuh, tipe kalus dan berat kering serta berat basah kalus.Data yang diperoleh dianalisis menggunakan analisis ragam (ANOVA) dengan tingkat kesalahan 1\% dan $5 \%$.Apabila menun-jukkan perbedaan yang nyata dilanjutkan dengan uji Beda Nyata Jujur (BNJ)atau uji Beda Nyata Terkecil (BNT).

\section{Hasil dan Pembahasan}

\section{Respon Pemberian Hormon 2,4-D dan BAP terhadap Prosentase Kalus yang Tumbuh}

Hasil analisis varian prosentase kalus yang tumbuh menunjukkan bahwa interaksi 2,4-D dan BAP berpengaruh sangat nyata terhadap persentase kalus yang tumbuh menjadi. Menurut Setyaningrum (2011), hal tersebut dikarenakan zat pengatur tumbuh yang terkandung dalam media kultur in vitro akan mempengaruhi pertumbuhan dan perkembangan eksplan. Selanjutnya Jonwaldinson (2010), semakin tinggi konsentrasi 2,4-D yang diberikan hingga $1,5 \mathrm{mg} / \mathrm{l}$ dalam kultur kalus, maka pertumbuhan kalusnya akan semakin meningkat.

Berdasarkan hasil uji lanjut BNJ menunjukkan bahwa kombinasi yang terbaik adalah $B_{1} D_{2}$ meskipun tidak berbeda nyata dengan $B_{0} D_{2}$ dan $B_{2} D_{0}$ dengan prosentase kalus yang tumbuh pada media tersebut mencapai $83,33 \%$ (Tabel 1.). Hal ini sejalan dengan tipe kalus embriogenik yang tumbuh pada perlakuan $B_{1} D_{2}$ mempunyai prosentase yang lebih tinggi, yaitu $100 \%$, sedangkan pada perlakuan $B_{0} D_{2}$ prosentase tipe kalus embriogeniknya hanya mencapai $75 \%$ dan pada perlakuan $\mathrm{B}_{2} \mathrm{D}_{0}$ hanya $50 \%$. 
Tabel 1. Uji BNJ Interaksi Hormon 2,4-D dan BAP terhadap Prosentase Kalus yang Tumbuh

\begin{tabular}{cccc}
\hline No. & Perlakuan & $\begin{array}{c}\text { Nilai rata- } \\
\text { rata }\end{array}$ & $\begin{array}{c}\text { Hasil Uji } \\
\text { BNJ }\end{array}$ \\
\hline 1 & $\mathrm{~B}_{2} \mathrm{D}_{2}$ & 33,33 & $\mathrm{a}$ \\
2 & $\mathrm{~B}_{2} \mathrm{D}_{3}$ & 33,33 & $\mathrm{a}$ \\
3 & $\mathrm{~B}_{3} \mathrm{D}_{1}$ & 33,33 & $\mathrm{a}$ \\
4 & $\mathrm{~B}_{3} \mathrm{D}_{3}$ & 33,33 & $\mathrm{a}$ \\
5 & $\mathrm{~B}_{0} \mathrm{D}_{0}$ & 41,67 & $\mathrm{ab}$ \\
6 & $\mathrm{~B}_{0} \mathrm{D}_{1}$ & 41,67 & $\mathrm{ab}$ \\
7 & $\mathrm{~B}_{3} \mathrm{D}_{2}$ & 41,67 & $\mathrm{ab}$ \\
8 & $\mathrm{~B}_{0} \mathrm{D}_{3}$ & 50,00 & $\mathrm{bc}$ \\
9 & $\mathrm{~B}_{1} \mathrm{D}_{0}$ & 58,33 & $\mathrm{~cd}$ \\
10 & $\mathrm{~B}_{1} \mathrm{D}_{1}$ & 58,33 & $\mathrm{~cd}$ \\
11 & $\mathrm{~B}_{1} \mathrm{D}_{3}$ & 58,33 & $\mathrm{~cd}$ \\
12 & $\mathrm{~B}_{2} \mathrm{D}_{1}$ & 58,33 & $\mathrm{~cd}$ \\
13 & $\mathrm{~B}_{3} \mathrm{D}_{0}$ & 66,67 & $\mathrm{~d}$ \\
14 & $\mathrm{~B}_{0} \mathrm{D}_{2}$ & 83,33 & $\mathrm{e}$ \\
15 & $\mathrm{~B}_{1} \mathrm{D}_{2}$ & 83,33 & $\mathrm{e}$ \\
16 & $\mathrm{~B}_{2} \mathrm{D}_{0}$ & 83,33 & $\mathrm{e}$ \\
\hline
\end{tabular}

Keterangan : angka yang diikuti huruf yang sama tidak berbeda nyata pada BNJ 5\%

Auksin penting untuk mengontrol pertumbuhan dan organogenesis pada kultur in vitro. Bermacam perkembangan seperti kalus, akar dan tunas dipengaruhi oleh konsentrasi zat pengatur tumbuh yang diberikan (Staba, 1980). Pemberian hormon 2,4-D memberikan pengaruh dalam merangsang perbesaran dan pembelahan sel untuk membentuk kalus. Perbesaran sel ini disebabkan oleh meningkatnya daya plastisitas dinding sel dan terbentuknya enzim selulase yang dapat melarutkan selulosa pada dinding sel, sehingga menyebabkan oksigen, air dan garam mineral mudah terabsorpsi melalui membran dinding sel sehingga terjadi pertumbuhan dan perbesaran sel (Wilkins, 1970). Penambahan BAP dalam media juga dapat mendukung pembentukan kalus. BAP mempunyai sifat mudah ditranslokasikan, aktif merangsang pertumbuhan kalus, serta aktif dalam meregenerasi kalus maupun tunas (Wiendi et al., 1991).

\section{Respon Pemberian Hormon 2,4-D dan BAP terhadap Tipe Kalus yang Terbentuk \\ Menurut Fowler (1983), pembentu-} kan kalus terjadi karena adanya pelukaan atau rangsang luka yang diberikan pada eksplan, sehingga sel-sel pada eksplan akan memperbaiki sel-sel yang rusak tersebut. Awalnya terjadi pembentangan dinding sel dan penyerapan air, sehingga sel akan membengkak selanjutnya terjadi pembelahan sel. Rangsang luka tersebut menyebabkan kesetimbangan pada dinding sel, sebagian protoplas mengalir ke luar dinding sel sehingga mulai terbentuk kalus, pada beberapa perlakuan dominasi warna kecoklatan menutupi permukaan kalus. Hal ini dapat terjadi sebagai akibat dari tingginya kandungan senyawa fenolik yang terbentuk serta menutupi permukaan kalus. Penelitian Nisa dan Rodinah (2005) juga mendapatkan beberapa eksplan yang mati akibat pencoklatan (browning). Pencoklatan salah satunya disebabkan oleh sintesis metabolit sekunder (senyawa fenolik). Adanya sintesis senyawa fenolik yang menutupi permukaan kalus akan menyebabkan terhambatnya pertumbuhan kalus pada perkembangan selanjutnya dapat mengakibatkan kematian eksplan. Selain itu, pada permukaan kalus juga cenderung keras karena terdapat jaringan yang menebal. Di samping itu, pertumbuh-an kalus yang terjadi memang belum mencapai tingkat yang maksimal.

Kalus dapat dibedakan dalam beberapa tipe morfologi yang bervariasi sesuai dengan penampilan luar dan teksturnya. Kalus secara umum diklasifikasikan menjadi kalus perkembangan atau kalus embriogenik, kalus proliferatif dan kalus senescens (Kesee et al., 1991 dalam Sugiyono, 1993). Rataan persentasenya dari seluruh tipe kalus yang terbentuk pada seluruh perlakuan tersaji dalam bentuk histogram pada gambar 1.

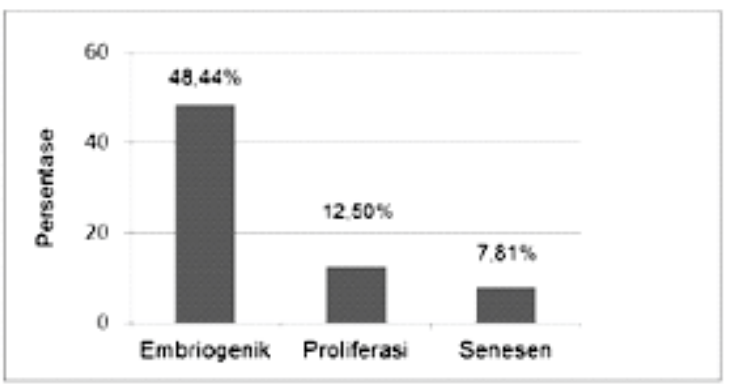

Gambar 1. Histogram rataan tipe kalus yang tumbuh pada seluruh perlakuan 
Berdasarkan hasil penelitian pada subkultur kalus selama 3 minggu terhadap kalus yang dihasilkan, didapatkan hasil ratarata prosentase kalus yang tumbuh pada seluruh perlakuan dengan tipe embriogenik sebesar $48,44 \%$, tipe proliferatif sebesar $12,50 \%$ dan tipe senescens sebesar $7,81 \%$. Menurut Kesse et al. (1990) dalam Sugiyono (1993), tipe kalus embriogenik adalah tipe kalus yang mampu berkembang ke arah embriogenesis somatik atau organogenesis somatik. Tipe kalus ini dicirikan oleh adanya klorofil, berwarna hijau, keras dan tumbuh dengan cepat. Kelebihan dari kalus embriogenik atau yang biasa disebut dengan kalus perkembangan yaitu merupakan kalus yang paling baik untuk digunakan pada regenerasi kalus (Taylor, 1993). Perlakuan $B_{1} D_{2}$ mempunyai persentase kalus embriogenik tertinggi dibandingkan dengan perlakuan $\mathrm{B}_{0} \mathrm{D}_{2}$ dan $B_{2} D_{0}$. Pembentukan kalus embriogenik dipengaruhi oleh konsentrasi zat pengatur tumbuh yang ditambahkan ke dalam media (Peterson dan Smith, 1991).

2,4-D sangat interaktif dalam merangsang pembelahan dan perbesaran sel dalam proses pembentukan kalus embriogenik, sehingga sel-sel lebih aktif melakukan perbesaran dan pembelahan dalam membentuk kalus embriogenik (Salisbury and Ross, 1995). Pembentukan kalus embriogenik pada penelitian ini mencapai $48,44 \%$, persentase ini lebih tinggi dari yang pernah dilaporkan oleh Kashefi (2008) dalam Wigyan (1994), yaitu sebesar $41,97 \%$ pada eksplan bunga jantan pisang. Menurut Hendaryono (1944), penambahan 2,4-D 2 mg/l mampu menginduksi kalus embriogenik sebanyak $75 \%$.

Selain kalus embriogenik, pada penelitian ini didapatkan prosentase pembentukan kalus proliferatif, yaitu sebesar $12,50 \%$. Menurut Nisa dan Rodinah (2005), kalus proliferatif adalah kalus yang mampu tumbuh namun tidak mampu berkembang ke arah embriogenesis atau organogenesis, tetapi selnya masih aktif membelah secara terus menerus. Tipe kalus proliferatif memiliki sel berukuran sangat kecil dan berwarna putih atau transparan. Dilihat dari tujuannya, apabila digunakan untuk regenerasi kalus untuk membentuk planlet, maka digunakan kalus embriogenik, tetapi apabila digunakan untuk subkultur lagi, maka kalus yang digunakan adalah kalus proliferatif. Persentase kalus senescens yang didapatkan pada penelitian ini sebesar $7,81 \%$. Kalus senescens merupakan kalus yang memiliki pertumbuhan yang lambat dan tidak menunjukkan perkembangan dengan ciriciri tidak terdapatnya klorofil, berwarna krem atau coklat. Terbentuknya tipe kalus senescens dan timbulnya gejala nekrosis sangat terkait dengan zat pengatur tumbuh yang digunakan (Kesse et al., 1991 dalam Sugiyono, 1993). Kondisi lingkungan pada kultur in vitro mempengaruhi pertumbuhan dan perkembangan kalus (Righetti et al., 1990 dalam Prayoga et al., 1997).

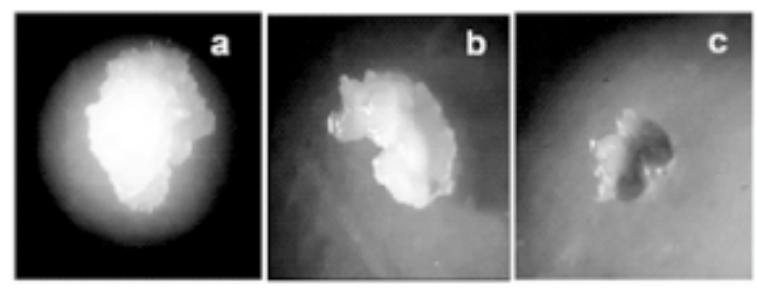

Gambar 2. Tipe kalus yang tumbuh ; a) embriogenik b) proliferatif c) senescens

Hasil pengamatan terhadap kalus yang tumbuh (Gambar 2.) diantaranya, tipe kalus embriogenik (Gambar 2.a.) yaitu ukuran sel kalus besar, berwarna putih kehijauan dan tumbuh cepat. Tipe kalus proliferatif (Gambar 2.b.) yaitu ukuran sel kalus kecil berwarna putih kekuningan. Tipe kalus senescens (Gambar 2.c.) yaitu kalus yang terbentuk berwarna coklat kehitaman dan tidak menunjukkan perkembangan kalus. Tipe kalus embriogenik yang paling banyak terbentuk yaitu pada perlakuan $B_{1} D_{2}$ mempunyai persentase yang paling tinggi dibandingkan dengan perlakuan yang lainnya. Hal ini menunjukkan bahwa perlakuan $B_{1} D_{2}$ relatif lebih baik daripada perlakuan lain dalam pembentukan kalus embriogenik. Tipe kalus proliferatif paling banyak terbentuk yaitu pada perlakuan $B_{1} D_{1}$ mencapai $50 \%$, sedangkan tipe kalus senescens paling banyak terbentuk yaitu pada perlakuan $\mathrm{B}_{2} \mathrm{D}_{0}$ mencapai $50 \%$.

\section{Respon Pemberian Hormon 2,4-D dan BAP terhadap Berat Basah dan Berat Kering Kalus Kedelai}

Analisa varian berat basah kalusmenunjukkan bahwa pemberian BAP maupun kombinasi 2,4-D dan BAP tidak berpengaruh nyata terhadap berat basah 
kalus, tetapi pemberian hormon 2,4-D secara mandiri berpengaruh sangat nyata terhadap berat basah kalus yang dihasilkan. Berdasarkan hasil uji lanjut BNT (Tabel 2.)menunjukkan bahwa pada perlakuan $D_{0}$ (kontrol)memberikan nilai rata-rata berat basah kalus lebih tinggi jika dibandingkan dengan perlakuan yang lain. Rata-rata berat basah kalus pada kontrol mencapai 0,0210 g. Pemberian 2,4-D dalam media akan menurunkan berat basah kalus. Hal ini di duga auksin endogen yang dimiliki eksplan cukup tinggi sehingga penambahan 2,4-D justru akan menghambat pertumbuhan kalus (Hendaryono dan Wijayani, 1994).

Tabel 2. Uji BNT Hormon 2,4-D terhadap Berat Basah Kalus Hasil Subkultur

\begin{tabular}{cccc}
\hline No. & Perlakuan & $\begin{array}{c}\text { Nilai rata- } \\
\text { rata }\end{array}$ & $\begin{array}{c}\text { Hasil Uji } \\
\text { BNT }\end{array}$ \\
\hline 1 & $\mathrm{D}_{0}$ & 0,0210 & $\mathrm{~b}$ \\
2 & $\mathrm{D}_{1}$ & 0,0110 & $\mathrm{a}$ \\
3 & $\mathrm{D}_{2}$ & 0,0107 & $\mathrm{a}$ \\
4 & $\mathrm{D}_{3}$ & 0,0102 & $\mathrm{a}$ \\
\hline
\end{tabular}

Keterangan : angka yang diikuti huruf yang sama tidak berbeda nyata pada BNT $5 \%$

Hasil analisis varian berat kering kalus menunjukkan bahwa interaksi 2,4-D dan BAP maupun pemberian hormon BAP secara mandiri tidak berpengaruh nyata terhadap berat kering kalus kedelai, tetapi secara mandiri pemberian hormon 2,4-D berpengaruh sangat nyata terhadap berat kering kalus yang dihasilkan.

Berdasarkan hasil uji lanjut BNT berat kering kalus menunjukkan bahwa pada perlakuan $\mathrm{D}_{0}$ (kontrol) memberikan nilai ratarata berat kering kalus lebih tinggi jika dibandingkan dengan perlakuan yang lain (Tabel 3). Rata-rata berat basah kalus pada media tersebut mencapai $0,0278 \mathrm{~g}$. Hal ini diduga konsentrasi 2,4-D yang diberikan terlalu tinggi. Adanya tekanan osmotik media yang lebih tinggi dibandingkan dengan tekanan osmotik yang ada dalam jaringan eksplan menyebabkan penyerapan hara menjadi terhambat, karena penyerapan hara pada media tersebut terhambat sehingga pertumbuhan dan berat kering kalus juga akan terhambat (Andaryani, 2010).
Tabel 3. Uji BNT 2,4-D terhadap Berat Kering Kalus Hasil Subkultur

\begin{tabular}{cccc}
\hline No. & Perlakuan & Nilai rata-rata & $\begin{array}{c}\text { Hasil Uji } \\
\text { BNT }\end{array}$ \\
\hline 1 & $\mathrm{D}_{0}$ & 0,0278 & $\mathrm{~b}$ \\
2 & $\mathrm{D}_{1}$ & 0,0186 & $\mathrm{a}$ \\
3 & $\mathrm{D}_{2}$ & 0,0162 & $\mathrm{a}$ \\
4 & $\mathrm{D}_{3}$ & 0,0160 & $\mathrm{a}$ \\
\hline
\end{tabular}

Keterangan : angka yang diikuti huruf yang sama tidak berbeda nyata pada BNT $5 \%$

Hasil yang sama didapatkan oleh Aniel Kumar et al. (2010), bahwa pembentukan kalus menjadi menurun pada media dengan pemberian 2,4-D dan NAA dalam konsentrasi yang lebih tinggi dari 1 $\mathrm{mg} / \mathrm{L}$, namun adanya penambahan 2,4-D ke dalam media kultur sangat diperlukan untuk menghasilkan kalus embriogenik (George dan Sherrington, 1984). Selama masa perkembangannya, kalus yang semakin lama berada pada media tanam akan mengalami degradasi fisiologis atau penurunan tingkat fisiologi tanaman akibat kekurangan unsur hara atau hormon tumbuhnya. Konsentrasi yang tinggi oleh 2,4-D dan tidak adanya penambahan sitokinin dalam media juga mampu memacu terjadinyasenesensi yang dapat menghambat proses pertumbuhan kalus (Yusnita, 2004).

Berat kalus yang berbeda pada setiap genotipe kedelai menunjukkan bahwa setiap genotipe kedelai mempunyai kemampuan berbeda dalam membentuk kalus. Hal ini dikarenakan setiap kedelai memiliki ukuran dan kondisi fisiologis jaringan eksplan yang berbeda. Menurut Fatmawati (2008) dalam Lizawati et al. (2012), peningkatan berat kalus terjadi karena kalus mengalami pembelahan sel hingga menyebabkan terjadinya peningkatan massa sel. Fitriyanti (2006), mengatakan bahwa tingginya berat basah kalus yang diperoleh berhubungan dengan struktur kalus yang diperoleh yaitu remah mencapai $95 \%$. Semakin remah kalus yang diperoleh, semakin cepat proses pembelahan selnya sehingga massa kalus makin banyak dan beratnya meningkat. 


\section{Kesimpulan}

Berdasarkan pembahasan disimpulkan bahwa pemberian hormon 2,4-D dan BAP dapat memacu pertumbuhan subkultur kalus kedelai.Kombinasi BAP 2 ppm dan 2,4-D 10 ppm merupakan kombinasi terbaik untuk prosentase kalus dan tipe kalus yang tumbuh, sedangkan pada berat basah dan berat kering kalus tidak dipacu oleh kombinasi pemberian hormon 2,4-D dan BAP.

\section{Daftar Pustaka}

Adisarwanto, T. 2005. Budidaya dengan Pemupukan yang Efektif dan Pengoptimalan Peran Bintil Akar Kedelai. Jakarta: Penebar Swadaya.

Andaryani, S. 2010. Kajian Penggunaan Berbagai Konsentrasi BAP dan 2,4-D terhadap Induksi Kalus Jarak Pagar (Jatropha curcas L.) secara In Vitro Cell. Dev. Biol. Plant, 29: 102-108.

Aniel Kumar, O., S. Subba Tata and T. Rupavati. 2010. In vitro induction of callusogenesis in chilli peppers (Capsicum annum L.). International Journal of Current Res, 3: 42-45.

Fitriyanti A. 2006. Efektivitas Asam 2,4-D dan Kinetin pada Medium MS dalam Induksi Kalus Sambiloto dengan Eksplan Potongan Daun. Skripsi. Universitas NegeriSemarang.

Fowler, M.W., 1983. Commercial application and economic aspects of mass plant cell culture, dari Mantell, S.H., Smith, $\mathrm{H}$. (ed.). Plant Biotechnoligy. Cambridge University Press, London, 3-38.

Gangga, E., H. Asriani dan L. Novita. 2007. Analisis Pendahuluan Metabolit Sekunder dari Kalus Mahkota Dewa (Phaleria macrocarpa (Scheff.) Boerl.). Jurnal IImu Kefarmasian Indonesia, 5 (1): 17-22.

George, E. F. and Sherington.1984.Plant Propagationby Tissue Culture. England: Exegetics Limited.

Gunawan, L. W.1988. Teknik Kultur Jaringan Tumbuhan. Laboratorium Kultur Jaringan Tumbuhan. Bogor : Pusat Antar Universitas (PAU) Bioteknologi IPB.

Hendaryono, D. P. S. dan A. Wijayani. 1994. Teknik Kultur Jaringan, Pengenalan dan Petunjuk Perbanyakan Secara Vegetatif. Kanisius, Yogyakarta.
Jonwaldinson. 2010. Pengaruh 2,4-D terhadap Induksi Embrio Somatik pada Berbagai Tipe Eksplan Tanaman Jarak Pagar(Jatropha curcas L). Skripsi.UniversitasJambi.

Kashefi, K. 2008. Organogenesis, Somatic Embryogenesis and Regeneration of Immature Male Flowers of Banana Cultivar. University Putra Malaysia.

Khumaida, N. dan T, Handayani. 2010. Induksi dan Proliferasi Kalus Embriogenik pada Beberapa Genotipe Kedelai. J. Agron. Indonesia, 38 (1) : 19-24.

Lizawati, Neliyati dan R. Desfira. 2012. Induksi Kalus Eksplan Daun Durian (Durio Zibethinus Murr. Cv. Selat Jambi) pada Beberapa Kombinasi 2,4D dan BAP. Fakultas Agrikultur Universitas Jambi, 1 (1): 23-34.

Nisa, C. dan Rodinah. 2005. Kultur Jaringan Beberapa Kultivar Buah Pisang (Musa paradisiaca L.) dengan Pemberian Campuran NAA dan Kinetin, Bioscientiae, 2 (2): 23-26.

Peterson, G and R. Smith. 1991. Effect of abscicic acid and callus size on regeneration of American and international rice varieties. Plant Cell Rep, 10: 35-38.

Prayoga, L., Sugiyono, E. S. Purwati dan M. Dwiati. 1997. Upaya Mendapatkan Bibit Tebu (Scharum officinalis L.) melalui Regenerasi Kalus dengan Pemberian Hormon BAP dalam Kultur Kalus Aseptis. Laporan Hasil Penelitian. Tidak Dipublikasikan. Fakultas Biologi Universitas Jenderal Soedirman.

Salisbury, F. B. dan C. W. Ross. 1995. Fisiologi Tumbuhan Jilid III. Penerbit ITB, Bandung.

Setyaningrum, R. 2011. Efektivitas 2,4Diklorofenoksi Asetat (2,4-D) dan Kinetin terhadap Induksi dan Kandungan Klorofil serta Karotenoid Kalus Alfalfa (Medicago sativa L.). Abstrak Skripsi. Tidak Dipublikasikan. Departemen Pendidikan Nasional Fakultas MIPA Universitas Diponegoro, Semarang.

Staba, E. J. 1980. Plant Tissue Culture as a Source of Biochemical. CRC Press, Inc. Bocaraton, Florida.

Sugiyono. 1993. Pengaruh Hormon 2,4-D dan BAP terhadap Multiplikasi Kalus Purwoceng (Pimpinella pruatjan Molken) pada Kultur Aseptis. Skripsi. Tidak Dipublikasikan. Departemen Pendidikan Nasional Fakultas Biologi Universitas Jenderal Soedirman. 
Syahid, S. F dan Hernani. 2001. Pengaruh Komposisi Media terhadap Pertumbuhan Kalus dan KadarTannin dari Daun Jati Belanda (Guazuma ulmifolia Lamk) secara Kultur In Vitro. Jurnal Littri, $16(1): 1-5$.

Taylor, P. W. J. 1993. Tissue Culture of Sugareane for Crop Improvement. Bureau of Sugar Experiment Stations, Queensland.

Wattimena, G. A. 2001. Zat Pengatur Tumbuh Tanaman. IPB, Bogor.
Widoretno, W., E. L. Arumningtyas dan Sudarsono. 2003. Metode Induksi Pembentukan Embrio Somatik dari Kotiledon dan Regenerasi Planlet Kedelai Secara In Vitro. IPB, Bogor.

Wilkins. 1970. The Physiology of Plant Growth and Development. Mc GrawHill, San Fransisco.

Yusnita.2004.KulturJaringanCaraMemperb anyakTanamanSecaraEfisien.Jakarta :Agromedia Pustaka. 